\title{
TANÁROK ÉRZELMEI - NEMZETKÖZI TRENDEK, HAZAI HELYZETKÉP AZ AFFEKTÍV PARADIGMA FÉNYÉBEN MESTERHÁzy MÁria
}

az Eötvös Loránd Tudományegyetem PPK Neveléstudományi Doktori Iskola doktorjelöltje dobmester@gmail.com

Jelen tanulmányban a tanárok érzelmeivel foglalkozó nemzetközi kutatási trendek bemutatására és a 2003-2016 között megjelent magyar publikációk tanári érzelmekre vonatkozó értelmezéseinek áttekintésére vállalkozunk. A kutatás célja, hogy számba vegye az eredményeket és a hiányokat, felhívja a figyelmet a terület fontosságára, és ezáltal további kutatásokat ösztönözzön. Nemzetközi áttekintö tanulmányokra támaszkodva felvázolom a tanári érzelmekre irányuló vizsgálatok kialakulásának okait, fontosabb témaköreit, a konceptualizáció problémáit és néhány modellt. A magyar szakirodalom vizsgálatakor az érzelmek, az érzelmi képességek és az érzelmekkel kapcsolatos nézetek hazai jelenlétét vizsgálom a pedagógus-, illetve osztálytermi kutatások egyes területein.

\section{A tanári érzelmek helye, értelmezése az affektív pedagógiai kutatásokban}

Az ember mentális világának három fő képessége a kogníció, azaz megismerő képesség, az effekció, azaz motiváció, akarat és az affekció, vagyis érzés, érzelem, hangulat (Bányai - Varga, 2014). Míg az 1990-es évekig a neveléstudományi kutatások előterében szinte kizárólag a kogníció állt, az évtized második felétől egyre élénkülő figyelem irányult az affektív jelenségek világa felé is. Fontos tisztázni, hogy az affektív kifejezést kettős értelemben használják a pedagógiai és pszichológiai szakirodalomban: a szükebb értelmezés csak az érzés, érzelem, hangulat jelenségeivel foglalkozik, míg a tágabb az affekció és effekció témaköreit együtt tárgyalja, vagyis az affektív kifejezést gyüjtőfogalomként használja (Pekrun - Linnenbrink-Garcia, 2014; Bányai - Varga, 2014). Józsa és Fejes (2012) tanulmánya, mely az egyik legjelentősebb hazai áttekintés, az attitüdöket, a tanulási motivációt, az áramlatélményt, az iskolai klímát és a tanuláshoz, neveléshez kapcsolódó érzelmeket veszi számba a tanulás affektív tényezői között. Míg a motivációról szóló szakirodalom súlya jelentősen nőtt az elmúlt évtizedben, az érzelmekre még mindig kevesebb figyelem irányul: „A tanulás hatékonysága, eredményessége és a tanulók érzelmei közötti összefüggések iskolai kontextusban még alig ismertek. A hazai kutatások csak kezdeti lépéseket tettek ezen területen" (Józsa - Fejes, 2012. 385. o.).

A tanári érzelmek kutatása beilleszthető az oktatáshoz kapcsolódó érzelmek tágabb témakörébe. A pozitív iskolai érzelmekkel leginkább a jóllét-, eredményesség- és flow kutatások foglalkoznak, itt a pozitív pszichológia hatása érzékelhető (Reinhardt, 2009; Hamvai - Pikó, 2008; Oláh, 2005). A negatív 
érzelmek közül az iskolai félelmekkel foglalkozó kutatások nagyobb hagyománnyal rendelkeznek, e téren jelentősek Rapos Nóra (2003) nézetkutatásai, melyek a tanulói félelmeket vizsgálva a tágabb társadalmi környezetre, így a családi háttérre is kitérnek.

\section{Az előkutatás tanulságai}

Kutatásomat megelőzően felderítő jellegű vizsgálódást végeztem a Matarka adatbázisban. Az affekció/emóció/érzelem szavakra és képzett alakjaikra, továbbá egy korábbi kutatást alapul véve (Mesterházy - Vámos, 2016) a tanárok körében leggyakrabban elöforduló érzelmekre is rákerestünk. Az így kapott eredményeket több szempontból szürtük:

1. Kizártuk a programismertetéseket és recenziókat, a nem pedagógiai tárgyú tanulmányokat, a terápiás, gyógypedagógiai, illetve módszertani jellegü írásokat, személyes tapasztalatok, vélemények megfogalmazását, konferenciabeszámolókat és interjúkat.

2. Kutatásnak akkor tekintettünk egy tanulmányt, ha világos módszertani háttérrel rendelkezett, továbbá vagy kutatáson alapuló szakirodalmi áttekintést vagy empirikus kutatást tartalmazott.

3. Végül kizártuk a csak tanulói perspektívát vizsgáló kutatásokat.

A fennmaradó tanulmányok körét az 1. táblázat szemlélteti.

1. táblázat: A Matarka adatbázisban egy kulcsszavas keresés alapján a tanárok érzelmeire vonatkozó kutatások

\begin{tabular}{|c|c|c|c|}
\hline Kulcsszó & Találatok & Elméleti áttekintés & Empirikus kutatás \\
\hline affektiv & 8 & $\begin{array}{c}1 \\
\text { Gombos-Bányai- } \\
\text { Varga, } 2009\end{array}$ & $\begin{array}{c}2 \\
\text { Szabadi, 2016a; } \\
\text { Kissné, 2009 }\end{array}$ \\
\hline érzelem & 101 & $\begin{array}{c}5 \\
\text { Réthyné, 2016; Bredács, } \\
\text { 2009; Reinhardt, 2009; } \\
\text { Zsolnai - Kasik, 2007; } \\
\text { Zsolnai - Rácz-Rácz, } \\
2008\end{array}$ & $\begin{array}{c}4 \\
\text { Szabadi, 2016b; } \\
\text { Mesterházy - Vámos, } \\
\text { 2016; Séllei, 2016; } \\
\text { Pauwlik-Margitics, } \\
2008\end{array}$ \\
\hline emóció & 6 & 0 & 0 \\
\hline öröm & 22 & 0 & 0 \\
\hline boldogság & 12 & 0 & 0 \\
\hline elégedettség & 4 & 0 & $\begin{array}{c}1 \\
\text { Harangi, } 2003\end{array}$ \\
\hline büszkeség & 0 & 0 & 0 \\
\hline
\end{tabular}


TANULMÁNYOK

\begin{tabular}{|l|c|c|c|}
\hline félelem & 9 & 0 & 0 \\
\hline szorongás & 10 & 0 & 0 \\
\hline stressz & 13 & 0 & 2 \\
& & & $\begin{array}{c}\text { Szelezsánné, 2016; } \\
\text { Salavecz-Neculai, } \\
\end{array}$ \\
\hline harag (düh) & 4 & 0 & 2006 \\
\hline szégyen & 2 & 0 & 0 \\
\hline unalom & 3 & 0 & 0 \\
\hline \multicolumn{1}{|c|}{ összes } & 194 & 6 & 9 \\
\hline
\end{tabular}

A téma megjelenésének néhány sajátossága az előkutatás alapján megállapítható. Kevés a kutatás, ugyanakkor rendkívül heterogén anyag lelhető fel a tanári érzelmekről. Számos olyan cikk lát napvilágot, ahol a tudomány határmezsgyéjén pedagógusok az érzelmekröl fogalmazzák meg nézeteiket, elemzik tapasztalataikat (például Hegyiné, 2001; Kazal, 2009); a pedagógustársadalom számára e téma fontosnak tünik. További megfigyelés, hogy az iskola világával kapcsolatos kutatások döntően a tanuló perspektívájára koncentrálnak. Az évszámok sejteni engedik az élénkülő figyelmet: a tanulmányok több mint harmada 2016-ban jelent meg. A tanulmányok ugyanakkor nagyon eltérőek mind elméleti hátterüket, mind módszereiket tekintve, így az áttekintéshez hiányzott egy tematikus szempontrendszer. A találatok meglehetősen alacsony száma azt a kérdést is felvetette, vajon milyen témákhoz kapcsolódva lehetne egy mélyebb szintủ kutatás során további adatokat gyüjteni? A választ a fenti kérdésekre a nemzetközi szakirodalom vizsgálatával reméltem megtalálni.

\section{A kutatás céljai, módszertani alapvetések}

Tanulmányomban a tanárok érzelmeivel kapcsolatos nemzetközi trendek bemutatására és az 2003 után megjelent vonatkozó magyar publikációk áttekintésére vállalkozom. Egy kutatási terület áttekintése sokféle célból történhet, melyet a kutató érdeklődése mellett meghatároz a téma jellege és kutatottságának mértéke. Az érzelmekre vonatkozó nemzetközi szakirodalomban a leggyakrabban megfogalmazott célkitüzés: felhívni a figyelmet e marginális helyzetben lévő terület fontosságára - tanulmányommal én is ezt szeretném szolgálni. Kutatásom az elméleti kérdések főbb pontjaira irányul: bemutatom az értelmezési keret kialakulásának okait, főbb jellemzőit, fontosabb témaköreit és néhány koncepcionális modellt. Feltárom, hogy milyen kutatási keretekhez kapcsolódva jelenik meg a tanárok érzelmeinek értelmezése, vizsgálom, milyen tényezőkre, összefüggésekre irányulnak kutatások. Munkám jelenlegi fázisában nem cél a minták, módszerek vagy eredmények összegzése, inkább egy helyzetkép felvázolása; továbbá megkísérlem kitapintani a nemzetközi kutatási trendek 
fényében azokat a pontokat, ahol az érzelmek kutatása erőteljesebben beléphet a hazai neveléstudomány világába. E célból az összegzésben ajánlásokat is megfogalmazok a kutatások lehetséges jövőbeni irányairól.

Vizsgálatom deduktív jellegü szakirodalmi elemzés, melynek megtervezésében Falus (2004) mellett Petticrew és Roberts (2006) módszertanára is támaszkodtam. Az áttekintés különösen hasznos lehet egy eddig még fel nem tárt terület esetén, egyik lehetséges célja a hiányok feltérképezése. „Nem csak az a fontos, hogy tudjuk, mit tudunk, hanem az is, hogy tudjuk, mit nem tudunk" (Lao Ce, idézi: Petticrew Roberts, 2006. 20. o). A módszertani kérdéseket részletesen tárgyalom a hazai kutatások bemutatásánál. Vizsgálatom nemzetközi részében a már létező áttekintő tanulmányok eredményeire támaszkodom. Bár a feltárás nem teljes körü, úgy érzem, a kutatás jelen szakaszában hasznos az eddigi eredmények összefoglalását a szakmai közönség elé tárni. A következő lépés egy teljes szisztematikus feltárás és az eredmények metaanalízise lehet.

\section{A tanárok érzelmeinek kutatása - nemzetközi trendek}

\section{Az érzelmek értelmezésének problémái és konceptualizációs törekvések}

A tanári érzelmek értelmezésének egyik forrása az affektív pszichológia érzelmekről alkotott felfogása. A különböző diszciplináris nézőpontok, eltérő elméletek, megközelítések, valamint számos nyitott kérdés ellenére néhány fontos vonásban egyetértés van. Az érzelmekre az affektív paradigmában úgy tekintenek, mint (1) a társas és természeti környezettel való megküzdés hasznos és alapvető eszközeire; (2) az affekció, kogníció és effekció kérdésköreit egymással összefüggésben tárgyalják; (3) az érzelmet olyan komplex, multidimenziós rendszernek fogják fel, amely hídszerepet tölt be egyrészt a tudat, másrészt a viselkedés irányában. Az érzelmek e felfogás szerint a következö, egymásra komplexen ható komponensekből tevődnek össze: (a) kognitív kiértékelés, (b) vegetatív arousal, (c) érzelemkifejezés, (d) gondolkodási és cselekvési tendenciák, (e) nyílt vagy kognitív aktivitás és (f) szubjektív élmény (Bányai - Varga, 2014).

A szociális-konstruktivista nézőpont is jelentősen hatott a tanárok érzelmeivel foglalkozó kutatásokra. Figyelemre méltó ebből a szempontból Schutz (2014) áttekintése. Hangsúlyozza, hogy a tanári érzelmekröl való gondolkodás olyan konstrukció, mely szorosan kapcsolódik ahhoz a történelmi-társadalmi realitáshoz, melyben élünk, amelyet értékelünk, s ez a világlátás meghatározza azokat a kutatási kérdéseket, amelyeket felteszünk. A kutatásra úgy tekint, mint problémamegoldó tevékenységre. A szociális-kulturális tényezők folyamatosan változó nyitott ökológiai rendszerek, a vizsgált jelenség erőteljesen függ e változó kontextustól. Az érzelmi epizódokban fontos szerepet tulajdonít a döntéseknek, melyek mögött a tanári célok, sztenderdek és nézetek állnak. A tanár az osztálytermi kontextusban dinamikus, kétszintű folyamat során értékeli ki a lezajló érzelmi epizódokat. Először 
fontosságát és saját céljaival való összhangját értékeli, majd megítéli, hogy képes-e kezelni az adott epizódot. E két kiértékelés meghatározó abban, hogy milyen érzelem keletkezik benne. Az érzelmi, kommunikációs és kapcsolati kötelékek központi szerepet játszanak a kiértékelésben. Meghatározó a tanár szerepfelfogása is az adott iskolai-társadalmi-politikai kontextusban. A tanuló is számos érzelmi epizódot él át a tanóra során. Mindkét fél folyamatosan törekszik rá, hogy megértse azokat a normákat, értékeket és viselkedésformákat, amelyet elvárnak tőle az osztálytermi kontextusban. A tanár ezeket értelmezve dönti el, milyen stratégiát választ az érzésekkel való megküzdés során.

Elméleti és módszertani szempontból is fontos a Fried, Mansfield és Fobozy (2015) által 82 tanulmány szisztematikus analízise alapján kidolgozott modell. Ennek összefoglalása látható az 1. ábrán.

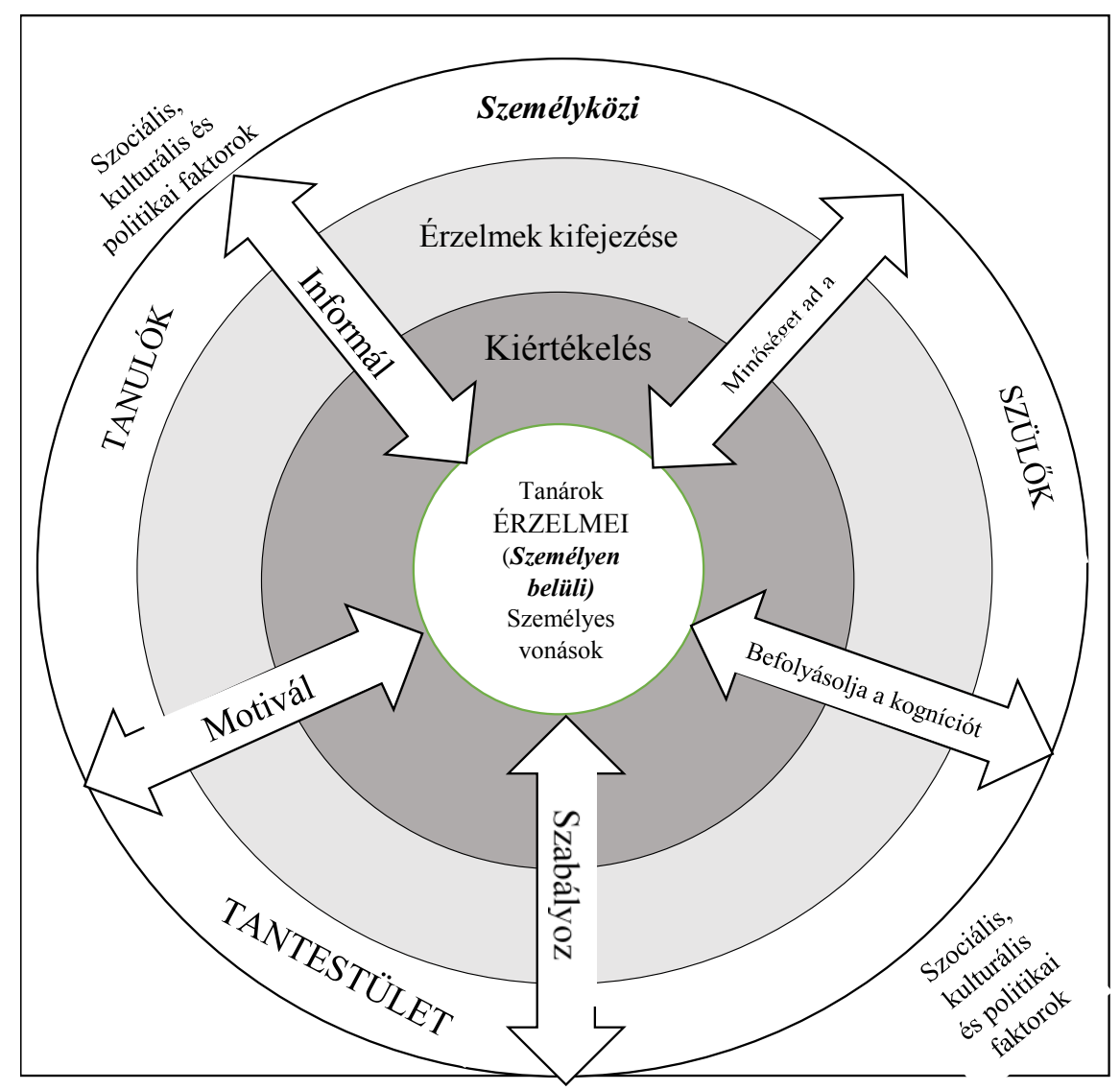

1. ábra: Tanári érzelmek, befolyásolási faktorok Fried-féle modellje (Fried és mtsai, 2015. 428. o.) 
Megállapították, hogy a tanárok érzelmeinek kutatása során személyen belüli (intraperszonális) és személyközi (interperszonális) tényezőket is vizsgálnak. A személyen belüli tényezők közé sorolható az identitás, a nézetek, az értékítéletek és a személyiség egyedi jellemvonásai. A közvetlen iskolai környezet személyközi tényezöi: a családok, a tantestület, az iskolai vezetés, az értékítéleten és az érzelmi kultúrán keresztül befolyásolják, hogy a tanár milyen érzelmeket érez és fejez ki a tanítás-tanulás során. Kiemelten fontos a kiértékelés szerepe, mely a személyen belüli szférát összeköti a személyközivel. A kulturális, szociális és politikai faktorok formálják azt a tágabb teret, mely meghatározza, hogy a tanár miért, mikor és hogyan kezeli, illetve fejezi ki érzelmeit.

A kutatók az érzelmek öt funkcióját azonosították, melyek e tényezőkkel kölcsönhatásban állnak. Az érzelmek (1) informálják a tanárt önmagáról és másokról, s ezáltal kapcsolatainak és identitásának felépítésében vesznek részt. A tanár-diák kapcsolat hatással van az osztálytermi munkára, például a pozitív érzelmek által a tanulási kedvre. (2) Az érzelemkifejezés minősége elsősorban az osztálytermi klímára és jóllétre, továbbá a (3) kognitív folyamatokra hat. A jó tanárok egyik jellemzője az érzelmek magas szintü (4) szabályozása, ugyanakkor túlzó formája összefüggésben állhat a kiégéssel. Az érzelmek a tanár és a tanulók (5) motivációjára is hatással vannak.

Figyelemre méltó Frenzel (2014) áttekintése, amelynek egyik fó szempontja a tanári érzelmek előfordulásának gyakorisága. Az öröm, büszkeség, harag, ingerültség, szégyen, unalom a leggyakrabban vizsgált érzelmek, a kapcsolódó affektív-motivációs tényezők közül a szerző kiemeli a burnout, az érzelmi munka, a lelkesedés és a teljesítménycélok szerepét. Az általa vizsgált empirikus tanulmányok a következő területeken bizonyítottak korrelációt a tanári érzelmekkel: a tanulók előmenetele, sikere pozitív élmény forrása a tanárok számára, míg az előmenetel hiánya negatív érzelmek kiváltója. Egyes kutatások szerint ez a viszony fordítva is fennáll; a tanulók rossz magatartása kulcsszerepet tölthet be a tanárok negatív érzelmeiben, a tanári érzelmek emellett hatással vannak a tanár-diák kapcsolatra és a tanár módszertani eredményességére is.

\section{Az értelmezési keret kialakulásának okai}

A tanárok érzelmeit értelmező koncepcionális keret megfogalmazása viszonylag új fejlemény a nemzetközi szakirodalomban is. A kutatók egybehangzó állítása szerint az 1990-es éveket megelőzően alig van a témába vágó kutatás (Pekrun - Schutz, 2007). Sutton és Wheatley 2003-ban megjelent áttekintő tanulmánya jelzi a megélénkülő érdeklődést. Azonosítják a hiány okait, az érzelmeket az affektív paradigma mentén értelmezik és a további kutatások iránti sürgetö igényt is fogalmazzák.

Sutton és Wheatley (2003) a kutatások hiányának fő okát abban látták, hogy a nyugati kultúrában egyfajta gyanakvással tekintenek az érzelmekre, melyeket 
irracionálisnak, destruktívnak vagy gyerekesnek tartanak szemben az értelem civilizált, felnőtt világával; a szerzők ezzel szemben az érzelmek pozitív szerepét és komplexitását hangsúlyozzák. Frenzel (2014) és Saric (2015) elemzése három fontos okot említ: (1) a tanulást a kutatók alapvetően kognitív tevékenységnek gondolják; (2) az objektív, érvényes és megbízható mérések nehézsége; (3) az érzelmet gyakran nőies, vagy feminista paradigmához tartozó „soft topic”-nak tartják.

Egy másik ok tudománytörténeti összefüggésekre vezethető vissza. A behaviorista paradigma időszakában csak periferiális törekvések voltak az érzelmek értelmezésére, részben bomlasztó, a viselkedést dezorganizáló válasznak tekintették, vagy csupán a motivációval együtt értelmezték (Pléh, 2014). A kognitív pszichológia szintén kevés figyelmet szentelt az affektív jelenségeknek, de fontos elörelépés volt, hogy felfigyeltek az információhordozó szerepre, továbbá kidolgozták a kognitív kiértékelés elméletét, amely az érzelmek és a kogníció közötti kapcsolat megértésében alapvető újdonságot hozott. Bár az affektív paradigma a pszichológia legdinamikusabban fejlődő területévé vált az 1980-as évektől, a pedagógiában csak lassan éreztette hatását (Sutton - Wheatley, 2003). A 90-es évek közepén az Egyesült Államokban a pályát elhagyó tanárok kritikusan magas száma azonban ráirányította a figyelmet az érzelmek fontosságára. A pályaelhagyás okait kutató jóllét-vizsgálatokban feltünt az érzelmi faktorok kiemelkedő szerepe: a stressz, az érzelmek kezelésének kudarca, az alkalmatlanság és felkészületlenség érzése, a negatív érzelmek túlsúlyba kerülése. A burnout és reziliencia vizsgálatok megindulása tovább árnyalta a képet. Az oktatási reformok kapcsán kiderült, hogy az elszámoltathatóság és a teszteredmények középpontba kerülése olyan érzelmeket váltanak ki, melyek befolyásolják a pedagógus viselkedését, az osztály légkörét, a tanár-tanuló kapcsolat minőségét (Fried és mtsai, 2015).

A tanári érzelmek kutatásának kialakulásában nem elhanyagolható a pozitív pszichológia hatása. Emellett az antropológia, a filozófia és különösen a szociológia felől érkező impulzusok jelentős szerepet játszottak a tanulás affektív dimenzióinak felfedezésében (Rosiek - Baghetto, 2009). A kutatások megélénküléséhez hozzájárul olyan új módszertani arzenál megjelenése, mely a pedagógusok életének rejtettebb természetü jelenségeinek vizsgálatát is lehetővé tette (Pekrun - Linnenbrink-Garcia, 2014).

A 2000-es évek második felétől az affektív kutatások megerősödését tapasztaljuk, ekkor többen megfogalmazzák a konceptualizáció szükségességét (Pekrun - Schutz, 2007). 2014-2015-ben különbözö szempontú áttekintések látnak napvilágot (Frenzel, 2014; Fried és mtsai, 2015; Saric, 2015; Schutz, 2014), melyek eredményeként értelmezési modellek jönnek létre. 


\section{Fontosabb témakörök}

A nemzetközi szakirodalomban mérvadóvá váltak Hargreaves (1998, 2001, 2008) kutatásai, aki az oktatásban bekövetkezett változások szemszögéböl vizsgálta a tanári érzelmeket: többek között a tanulókkal, kollégákkal, illetve szülőkkel való kapcsolatot, az érzelmi közelséget/távolságtartást, emellett az oktatás rendszerével, a pedagógiával, a tantervvel kapcsolatos affektív jelenségeket is. Hangsúlyozza, hogy a tanár döntéseit, gondolkodásmódját vagy az oktatási reformokhoz való viszonyulását nem lehet megérteni az érzelmek centrális szerepének figyelembe vétele nélkül. Nézete szerint az oktatási reformok tervezésénél sokkal erősebben kellene számolni a tanári hivatás érzelmi jellegével. A tanítás-tanulás folyamata ugyanis olyan érzelmi gyakorlat, mely érzelmi megértést kíván, a tanár intenzív érzelmi munkát végez, melynek során érzelmeit kezeli és szabályozza a hatékonyság érdekében, ami elválaszthatatlan a tanár morális céljaitól és attól a képességtől, hogy ezeket a célokat elérje. „A jó tanítás tele van pozitív érzelmekkel. Nem csupán attól függ, hogy az ember tudja-e az anyagot, hatékony-e, megvannak-e a megfelelő kompetenciái, vagy megtanulta-e az összes jó technikát. A jó tanár nem csupán megfelelően olajozott gépezet. Érzelmekkel teli, lelkes lény, aki összekapcsolódik tanítványaival; munkáját és az osztályt élvezetes élményekkel, kreativitással, kihívásokkal és örömmel tölti meg." (Hargreaves, 1998. 835. o.). Az oktatási reformok és az érzelmek kapcsolatát számos további szerző vizsgálta (Zembylas, 2010; Van Veen - Sleegers, 2006).

A tanári professzió erőteljes emocionális karaktere, ebből adódó sérülékenysége, a tanár érzelmi menedzsmentje szorosan kapcsolódik az elvárt érzelmi szerepek kérdésköréhez is (Oplatka, 2009). További fontos vizsgálati téma a tanári pályaszakaszok, különösen a kezdő tanárok és a mentortanárok érzelmi jellegzetességei (Bullough, 2009). Schutz, Cross, Hong és Osbon (2009) szerint a szakmai identitás gyakran az érzelmeken keresztül fejeződik ki. Az érzelmek szerinte leginkább két módon befolyásolják a nézeteket: újak kialakulásához, valamint a meglévők megváltozásához vezetnek. Egyes kutatók kiemelik, hogy az érzelmek kulcsszerepet játszanak a tanári identitás konstruálásában is, ami meghatározó szerepet tölt be a sikeresség érzetében s ezen keresztül a jóllét pozitív vagy negatív alakulásában; hatnak emellett a tanár érzelemkezelésére, a tanár-diák kapcsolatra, továbbá arra, hogy képes-e egyensúlyban maradni a kihívást jelentő körülmények között (Day és Quing, 2009). Korunkban a pedagógusnak számos, a környezet felől érkező kihívással kell szembenéznie, föleg a családi struktúrák és szerepek átalakulása, valamint az iskolai tanulás leértékelődése miatt az információs társadalomban, ami a szakmai identitás sérülékenységéhez és bizonytalanságához vezet. Számos vizsgálat középpontjában az osztálytermi történések állnak, vagyis az a kérdés, hogy a tanári érzelmek hatása hogy tükröződik a tanár és tanuló kapcsolatában, motivációjában, az alkalmazott módszerekben vagy az osztálytermi klímában (Fried és mtsai, 2015). 
A felsorolt témákat és értelmezési kereteket a kutatás során megkíséreltem tematizálni. A tanári érzelmek vizsgálata nézetem szerint három körülhatárolható kutatási terület találkozásában áll: (1) a kutatások valamilyen affektív tényezőt és/vagy (2) a tanári professzió érzelmi jellemzöit és/vagy (3) az osztálytermi munka érzelmi összetevőit vizsgálják. Az affektív tényezők tekintetében megkülönböztethetünk három szintet: (1a) a vizsgálatok egy részének középpontjában maguk az érzelmek, érzések és hangulatok állnak; (1b) másik részük az érzelmeket menedzselő képességekre: az érzelmi intelligenciára és kompetenciára vonatkozik; (1c) egy harmadik csoportjuk az érzelmekről alkotott nézetekre és az identitásra koncentrál. Az osztálytermi munkában föleg az affektív tényező (2a) eredményességre, $(2 b)$ tanár-diák kapcsolatra, (2c) motivációra, (2d) klímára és (2e) módszerekre tett hatását vizsgálják. A tanári professzió szempontjából a (3a) szerep, (3b) jóllét, (3c) elégedettség, (3d) mentális egészség és stressz, továbbá (3e) kiégés és (3f) érzelmi munka összefüggésében vizsgálódnak. A kapcsolódó értelmezési kereteket a 2. ábrán összegeztem.

\section{Tanári professzió} jellenzői

a) tanári szerep

b) jóllét

c) elégedettség

d) mentális egészség

e) kiégés

\section{1) érzelmi múrika}

1. Érzelmi tényezők

a) érzelmek, érzések, hangulatok

b) érzelmi intelligencia, érzelmi kompetencia

c) érzelmekröl alkotott nézetek, identitás
2. Osztálytermi interakciók

a) eredményesség,

b) tanár-diák kapcsolat

c) motiváció

d) klíma

e) módszerek

2. ábra: Tanárok érzelmeihez kapcsolódó legfontosabb értelmezési keretek rendszere 


\section{A hazai szakirodalom vizsgálata}

\section{A kutatás céljai, kérdései és az alkalmazott módszerek}

A hazai szakirodalom vizsgálatának célja annak feltárása, hogy vannak-e a tanárok érzelmeire, érzelmi intelligenciájára és kompetenciájára, valamint érzelmekkel kapcsolatos nézeteire irányuló kutatások, illetve a tanári professzióval és osztálytermi munkával kapcsolatos kutatásokban megjelennek-e, és milyen összefüggésekben értelmezve a vizsgált affektív tényezők. Az alábbi kérdésekre kerestem a választ:

1. Találunk-e olyan hazai kutatást, amely kifejezetten valamelyik affektív tényezőre irányul?

2. A tanári professzióval kapcsolatos kutatások elméleti alapozásaiban találunk-e a vizsgált affektív tényezőkre vonatkozó értelmezést?

3. Az osztálytermi munkával kapcsolatos kutatások elméleti alapozásaiban találunk-e a vizsgált affektív tényezőkre vonatkozó értelmezést?

A lehatárolásnál a következő szempontokat vettem figyelembe: a tanárok fogalma alatt az általános és középiskolai korosztályt tanítókat értem. Jelen kutatásban nem foglalkozom a gyógypedagógiai, vagy érzelmi zavarokkal és inkluzív neveléssel kapcsolatos cikkekkel. A nemzetközi értelmezési keret kialakulását figyelembe véve időbeli korlátként 2003-at határoztam meg, ${ }^{15}$ a kutatást 2016 végén zártam le. Az áttekintett tanulmányok köre a következőképpen alakult:

1. A Pedagógusképzés, valamint a Magyar Pedagógia számai.

2. Áttekintö tanulmányok az adott témakörben.

3. A témába vágó disszertációk köre a doktori.hu honlapon.

4. A fenti forrásokból származó tanulmányok hivatkozásaiban található publikációk köre.

A kutatást a 2. ábrán található minden egyes témakörre vonatkozóan külön-külön elvégeztem, azaz a témába vágó tanulmányokat kigyüjtöttem és megvizsgáltam, van-e bennük érzelmekkel kapcsolatos elméleti fejtegetés vagy kutatás.

\section{Érzelmi tényezök jelenléte és értelmezése}

Kifejezetten a tanárok egy meghatározott érzelmét vagy érzelmeit középpontba helyező kutatást a magyar szakirodalom vizsgált részében nem találtam.

Az érzelmi intelligencia területén három vonatkozó pedagóguskutatást találtam. Pauwlik és Margitics (2008) pedagógusjelöltek érzelmi intelligencia összetevőit tárja fel, összefüggéseket a nemi és korosztályi jelleggel kapcsolatban vizsgál. Baracsi (2013) kutatása a Goleman képességalapú modelljéhez kapcsolódó, CASEL programban kidolgozott kompetenciaterületekre épül, melyet saját eszközzel vizsgál.

${ }^{15}$ Sutton és Wheatley (2003) tanulmánya ebben az évben jelent meg, Fried, Mansfield és Dobozy (2015) is ezt a dátumot vették alapul áttekintésükhöz. 
Abból a kérdésből indul ki, hogy a tanárok meg tudnak-e felelni az új szerepelvárásoknak a személyes és társas kompetenciák területén. Hangsúlyozza a kiégés, az érzelemszabályozás, az önmegvalósító képesség, a megküzdési stratégiák, az elégedettség kapcsolatát az érzelmi intelligenciával, az értelmezés hátterében sejthető az a gondolat, hogy a vizsgált képességeket olyan tanárok tudják formálni, akik maguk is kompetensek. A vizsgálat során az érzelmek észleléséről, megértéséről, szabályozásáról, problémamegoldásban való használatáról és a kapcsolati képességekről gyüjt adatokat; nem vizsgálja a tanár érzelmi intelligenciájának tanulóra tett hatását.

Séllei Beatrix (2016) tanulmánya az újabb szemlélet megjelenését jelzi. Kutatásának hátterét a pedagógustársadalom érzelmi életét befolyásoló változások képezik. Az előkutatás során a változások elfogadásához, kezeléséhez szükséges képességeket térképezte fel pedagógusokkal folytatott fókuszcsoportos beszélgetések során. A pedagógusok által kiemelt legfontosabb tényezők a kitartás, kreativitás, optimizmus, nyitottság, empátia, tisztelet, együttmüködés, problémamegoldás, önérvényesítés, hála, önismeret, türelem, rugalmasság, elfogadás, bátorság, alázat, csapatmunka, stressz kezelés, önreflexió, célok, rendszerszemlélet voltak. Ezekhez való illeszkedés alapján választotta ki Bar-On vonásalapú érzelmi intelligencia modelljét széles körben végzett vizsgálata számára. A szerző hangsúlyozza az érzelmi kompetenciák kulcsszerepét a tanári hivatásban, kutatásának célja a magyar pedagógustársadalom érzelmi térképének felrajzolása.

Az érzelmi kompetenciák témakörével a magyar neveléstudományban elsősorban a Szegedi Tudományegyetemen Zsolnai Anikó által vezetett Szociális Kompetencia Kutatócsoport publikációi foglalkoznak. Alapos áttekintő tanulmányaik feltárják az érzelmi és szociális képességek összefüggéseit, az értelmezések, modellek fejlődését a szociális kompetencia keretében (Zsolnai - Kasik, 2007; Zsolnai 2015), emellett az érzelmek vizsgálata több programjukban is megjelenik, ${ }^{16}$ a szociális és érzelmi tanulás (Social and Emotional Learning) szakirodalmának bemutatásával a program implementációja felé fontos, ösztönző lépést tettek (Zsolnai - Rácz - Rácz, 2008). Döntően tanulókra fókuszáló vizsgálataikban a szülök mellett a pedagógusok is szerepelnek adatszolgáltatóként, a pedagógusok és a szülők megítélésének különbségét is elemzik (Kasik, 2015). Több publikációjukban is foglalkoznak a pedagógusok szociális kompetenciáival (Tóth - Kasik, 2010). Zsolnai (2004) a tanításhoz szükséges szociális készségek között említ érzelmi jellegüeket is, így a nonverbális kommunikációt, a kifejezőkészséget, a tanulói magatartás felismerését. A három legfontosabb pedagógiai alapképességnek a feltétel nélküli elfogadást, az empátiát és a hitelességet tekinti. Szabadi Magdolna (2016a, 2016b) tanulmányai jelzik, hogy az érzelmi képességek vizsgálata a tanárok kompetenciájának témaköre

${ }^{16}$ A SEL programhoz kapcsolódóan végeznek összehasonlító vizsgálatokat a szakképzés területén, emellett a szociális kompetencián belül vizsgálják érzelmi összetevők kapcsolatát, fejlettségét és fejlődését. 
felé is kezd kiterjedni. Az általa fejlesztett és kipróbált mérőeszköz a nemzetközi szakirodalom egyik leggyakrabban használt modelljére, az úgynevezett affektívszociális modellre épül. Az eszközfejlesztés új fejezetet nyithat a tanári érzelmek empirikus vizsgálatában, módszertani kutatásai pedig a képességek támogatása szempontjából tárnak fel új lehetőséget, a múvészetterápia eszközeinek bevonásával.

Az érzelmekkel kapcsolatos nézetek témakörében elöször a nézetfogalom értelmezését tekintettem át. Az érzelmek és nézetek közötti összefüggés kevésbé hangsúlyosan jelent meg a szakirodalmi értelmezésekben, inkább a nézetek és a cselekvés (Falus, 2006; Golnhofer - Nahalka, 2001), vagy a kogníció és a nézetek (Hercz, 2007) kapcsolatára helyezték a hangsúlyt. A nézetek és érzelmek összefüggésére vonatkozó megközelítéseket Kálmán (2009) foglalja össze a legrészletesebben. A nézetrendszert a tudásrendszer részének tekinti, mely affektív elemeket is tartalmaz: érzelmekkel telített, van értéktartalma, nem logikusan szervezett, személyes elköteleződéssé alakul - szemben a fogalomrendszerrel, melyben a kognitív jelleg erősebb (Kálmán, 2009. 40. o.). Az attitüd és érzelem elkülönítésének is az affektivitás az alapja, az attitüdöt inkább érzelmi, míg a nézetet inkább kognitív jelenségnek fogják fel (Falus, 2001; Dudás, 2006; Hercz, 2007). Összességében azt mondhatjuk, hogy a szakirodalom érzelmi telítettség szempontjából a tudás és az attitüd között helyezi el a nézeteket.

Az érzelmekkel kapcsolatos nézetek feltárására tett kísérletet Mesterházy és Vámos (2016) esettanulmánya. A kutatás célja többek között az érzelmekkel kapcsolatos nézetek vizsgálatára alkalmas kvalitatív és kvantitatív eszközök kipróbálása volt, az érzelmek átélését, küldését, fogadását, tudatos kommunikálását, a negatív érzelmekkel való megküzdést, az empátiát és az érzelmi önhatékonyságot is vizsgálták. Az áttekintett nézetkutatások közül még Tóth Edit (2011, 2015; Tóth Sipos, 2014) foglalkozik témánkat érintő területtel, a rendszerszintü mérések tanítási folyamatra gyakorolt hatásával. A rendszerszintủ mérésekre épülő elszámoltatási rendszerekben a tanárok nyomásgyakorlást érzékelnek, ami hatással van az osztálytermi munkára, például negatív hatással lehet a kreativitásra, a tanárok módszertanilag és a tartalomközlés esetében is szabályozva érzik magukat a tanórákon. A nyomásgyakorlás több szereplő felől is érkezhet, és mértéke függ a befolyásolás lehetőségétől, illetve az érintettség mértékétől. Kutatásaiban többek között arra keresi a választ, hogy a pedagógusok mennyire érzékelik ezt a kényszerhatást, és milyen mértékü nyomást gyakorolnak rájuk a különböző szereplők.

Az identitást Kálmán (2013) a nemzetközi szakirodalmat vizsgálva a nézetek mögött álló szélesebb, ugyanakkor mélyebb ernyőfogalomnak tekinti, kiemeli mozgékonyabb, érzelmekkel áthatott vonását. Az identitás és érzelmek kapcsolata feltáratlan, sokat ígérő, új kutatási terep lehet a jövőben, összhangban a nemzetközi tendenciákkal. 
Érzelmi jellemzők, összefüggések jelenléte a tanári professzióhoz kapcsolódó értelmezésekben

Nem találtam olyan kutatást sem, mely középpontba állítva értelmezné a tanári szerepek érzelmi jellemzőit, ugyanakkor a kutatások elméleti kerete kirajzolta azokat a fontosabb társadalmi, történelmi, politikai tényezőket, amelyek feltehetően befolyásolják a pedagógusok érzelmeit. A tanulmányok már a rendszerváltoztatást követően a pedagógusszerep kríziséről, szerepkonfliktusokról beszélnek. Az élethosszig tartó tanulás és a kompetenciaalapú oktatás paradigmája olyan szerepváltást vár a pedagógustól, amelyet - különösen az idősebb generáció nehezen tud megtenni, ami tantestületen belüli konfliktusokhoz vezet. Néhány kutatás arra hívja fel a figyelmet, hogy a pedagógusokra irányuló kompetenciaelvárások és jelenlegi valós személyiségállapotuk között komoly eltérés tapasztalható (Gáspár - Holecz, 2005; Szebeni, 2010; Baracsi, 2010). A kapcsolati szerep jelentőségét növeli az információs társadalomban a pedagógus ismeretközlő szerepének háttérbe kerülése (Bakos, 2015). A különböző irányból érkező elvárások - a tanuló a gondoskodó, a szülő, az ismeretközlö, a fenntartó, az adminisztrátor szerepet helyezi elötérbe - növelik a túlterheltséget (Szebeni, 2010). A pálya elnőiesedése szintén meghatározó, kevéssé kutatott szerepproblémák forrása (Kovács, 2011; Thun, 2012). Czövek Andrea (2011) szerint, míg az elitiskolák világában a hagyományos pedagógusszerep fenntartható, addig a heterogén csoportokkal dolgozó pedagógusok hagyományos eszközökkel nem kezelhető problémákkal találkoznak.

A tanárokra nehezedő fent jelzett problémák, valamint a folyamatosan változó oktatási környezet, sejthetően feszültségek, bizonytalanság forrása a pedagógustársadalomban. Hunyady György (2015) nézetkutatása is ezt látszik alátámasztani. Kiemeli, hogy a pedagógusok által leginkább preferált értékek (környezetvédelem, szociális biztonság, egyenlöség, türelem) a nyugalom és megnyugvás igényét fejezik ki, továbbá nagy a különbség az igényelt értékek és az érzékelt valóság között. Ehhez járul a szakma társadalmi alulértékeltsége: a tanárok az értelmiségnek általában, és hozzájuk mérve önmaguknak szerény pozíciót tulajdonítanak a társadalmi hierarchián belül.

Az oktatási reformok és tanári érzelmek kapcsolatának szempontja újabban megjelent a hazai gondolkodásban is (Halász, 2015; Séllei, 2016). Az érzelmi munka, erőfeszítés és menedzsment tanári professzióra vonatkozó értelmezésével azonban egyetlen tanulmányban sem találkoztam.

Reinhardt (2009) a pozitív érzelmek lehetséges hatását elemzi iskolai környezetben a tanuló és a tanár oldaláról is. Feltételezi, hogy csak olyan pedagógusok tudnak pozitív módszereket érvényesíteni, akik maguk is kiegyensúlyozottak, gazdag érzelmi világúak. Ennek érdekében szorgalmazza azokat az intervenciókat, melyek megelőzik a kiégést az egyre nehezedő körülmények között, és segítenek megtartani a pedagógusok fizikai, pszichés és 
mentális egészségét. Réthy Endréné (2015) tanuló tanárok körében végzett vizsgálatot elégedettségük, jóllétük, boldogságuk tekintetében. A tanulmánykötetben egy teljes fejezetet szentel a pozitív érzelmek és légkör tanulóra és tanulásra tett hatásának. Elemzi az iskolai jóllét összetevőit, javaslatokat fogalmaz meg arra nézve, hogy válhatna az iskola örömforrássá, amiben fontos szerepet tulajdonít a tanár reflektivitásának, toleranciájának, empátiájának, motiváltságának. Kiemeli, hogy a tanár emocionális állapotának hatása a tanulókra mindmáig nem került a vizsgálatok fókuszába annak ellenére sem, hogy a szülők és kortársak mellett ez a legerősebb érzelmi kötelék. Olyan intézkedéseket sürget, melyek segítenek a tanároknak érzelmi nehézségeik kezelésében, mert ennek hiányában „még több érzelmi zavart, problémát kell átélniük a tanulóknak." (Réthy, 2015. 107. o.) Holecz és Molnár (2014) a boldogság és jóllét, flow-élmények, erények és erősségek Seligman-féle modellje közötti kapcsolatot vizsgálta.

Yassur (2001) a tanári elégedettséget értelmezve a nemzetközi szakirodalom alapján kiemeli, hogy a döntési folyamatokban való részvétel és a szakmai önállóság különösen fontos a tanári elégedettség, a pályán maradás, elkötelezettség és hatékonyság szempontjából, az iskolai átszervezési folyamatok pedig magasabb stresszt jelentenek és növelik a kiégés kockázatát.

A kutatások alapján a pedagógusok közérzetét, elégedettségét inkább belső, mint külső tényezők határozzák meg Füzi (2012) szerint a tanár jó közérzetének legfontosabb belső tényezői: személyiségének kiteljesítése és elégedettség a munkában, jövőkép a pályán, a saját tanárideál elérhetőségének érzete. Hercz (2005) az elégedettséget a szakmai énkép részének tekinti, mely a célrendszerekről, helyzetükről, eredményességükről és elégedettségükről alkotott összkép és fontos alakítója a tanár-diák viszony, amit vizsgál is tanulmányában. Az elégedettség tényezöit a társadalmi és anyagi megbecsültség, a szakmai célok és ambíciók, továbbá az iskolai kapcsolatok (tanítványok, kollégák, szülők, vezetés) mentén tematizálja. Elégedettséggel kapcsolatos kutatást végzett Harangi (2004) is, saját kidolgozású kérdőívének 74 kérdése lényegében hasonló tematikát követ, de tárgyi feltételekre vonatkozóan is vizsgálódik. Két kérdése kifejezetten érzelmi jellegü tényezőre (a pálya szeretete, sikerélmények gyakorisága) vonatkozik, a továbbiakban a pályaelhagyási szándék és az elégedettség közötti összefüggéseket is vizsgálta (2003).

Holecz Anita (2015) és munkatársai számos vizsgálatot végeztek 2000-től napjainkig, ahol a pedagógusok és pedagógusjelöltek személyiségének állandó és változó tényezőit, továbbá a stressz, megküzdés és kiégés jellemzőit, és a pályamotivációt vizsgálták. Az eredményeket elemezve rámutat a pedagóguspálya stressz-szel telített voltára, melyben szerepet játszik a fizetés mértéke, a munkahelyi túlterheltség, az adminisztráció, a kapcsolatápolásra fordítható idő hiánya, a munkanap hosszúsága, a tanulókkal, vezetőkkel, kollégákkal kapcsolatos problémák, a munkahely és magánélet összeegyeztethetetlensége, az állásvesztés és a presztízs. A burnout-szindróma faktorait: az emocionális kimerülést, 
deperszenalizációt és a személyes hatékonyság csökkenését négy vizsgálatukban mérték pedagógusoknál. Az eredmények összevetésének célja a tanárképzés számára megfogalmazható tanulságok levonása volt.

Salavecz és Neculai (2006) is a pedagógusok munkahelyi erőfeszítései és kiégése közötti összefüggésre hívja fel a figyelmet, amit a munkakörülmények miatti frusztráció felerősíthet. Legújabban Szelezsánné (2016) végzett vizsgálatot e téren. A negatív jelenségek megközelítésében újabb modellekre is támaszkodik, így a stressz és kiégés mellett vizsgálja a munkahelyi pszichoterror (mobbing) jelenségét. Hipotéziseiben összefüggést feltételez a köznevelésben végbemenő állandó változás és a kifáradás között, továbbá a túlterhelés és a negatív jelenségek között, emellett konfliktuskezelési technikák és kompetenciák hiányát feltételezi. Suplicz (2012) a kiégés okának a kapcsolati túlterheltséget tartja és a gyenge, de hiteles kapcsolatok kialakításában látja a megoldást. Füzi (2012) a kiégés egyik lehetséges magyarázatát a tanulókkal kapcsolatos kudarcokban keresi, amennyiben azt a tanár nem képes beépíteni fejlődésébe. A kiégés megelózésének és kezelésének fontosságát hangsúlyozva Antalka Ágota (2015) emellett felhívja a figyelmet a tanár mintaadó szerepére a tanulók életében a stresszkezelés, problémamegoldás, attitüdök és viselkedés terén.

Érzelmi jellemzők, összefüggések jelenléte az osztálytermi munkával kapcsolatos kutatásokban

Józsa és Fejes (2012) áttekintése alapján feltehető, hogy a tanárral való kapcsolat leginkább a kisiskolások attitüdjében és motivációjában, különösen az iskolakezdéskor játszhat fontos szerepet, később a kortársakhoz való kapcsolat jelentősége erősödik. A középiskolai korosztály számára a tanár inkább szaktekintélyként, mintaadóként tünik fel. A tanulói motiváció és attitüd csökkenésében szerepet tulajdonítanak a tanárváltásoknak.

A tanárok motivációban, önszabályozó tanulásban betöltött szerepét Katona Nóra (2009) elemzi. A teljes személyiségre reflektáló, a szeretet és elfogadás szükségletének kielégítésére törekvő pedagógus szerepét hangsúlyozza a negatív jelenségek, például szülői bántalmazás ellensúlyozásában, a kortárs kapcsolatok kialakulásának segítésében, a tanulók iskolához való pozitív kapcsolatának támogatásában, különösen a veszélyeztetett gyermekek esetében a tanár által kezdeményezett kapcsolatépítéssel, a kölcsönös bizalom megteremtésével, a nyitott kommunikációval és a segítő szándék kifejezésével. Kiemeli a következetes, spontán, változatos és öszinte, a tanuló teljesítményét informatívan értékelő, a diák teljesítményéhez viszonyított dicséret szerepét, melynek eredménye a tanuló és tanár közötti kölcsönös tiszteletérzés kialakulása. A büntetés hatékonyságának alapja a tanuló érzelmi ragaszkodása, szeretetkapcsolata a tanárral. A tanár aktív segítséget nyújthat a tanulónak az extrinziktől az intrinzik motivációig bejárt úton. Ennek első lépése a bevetitett szabályozás, amikor a tanuló motivációja még erősen érzelmi 
jellegü. A pedagógus ennek kialakulását akkor tudja segíteni, ha jól bánik referens hatalmával és személyes vonzerejével. Ilyen például a gondoskodás, az igazságosság és a tisztelet, a lelkesedés, az élet iránti nyitottság. Az integrált szabályozást, a tanár akkor tudja segíteni, ha modellként képes megjelenni, emellett érvelni tud a kívánt cselekvés érdekében. Az optimális kihívások megteremtése, a hatékonyságérzetet növelő visszajelzések, az önértékelést tisztelettel kezelő magatartás szintén az intrinzik motiváció kialakulását segíthetik.

A tanár hatékonyságát befolyásoló affektív tényezőket Gombos, Bányai és Varga (2009) is elemzi. Hangsúlyozzák az iskola érzelmi nevelésben betöltött szerepét és az érzelmek, hangulatok megismerő folyamatokra gyakorolt döntő hatását. A nevelést szociális befolyásolásként értelmezik, melynek alapja a szeretet vagy a félelem. A szuggesztív tanáregyéniséget, az érzelmekre is ható oktatási módszereket, például érvelést és a szuggesztív kommunikációt emelik ki. Említik a tanári elvárások önbeteljesítő hatását, kérdőívvel vizsgálták a szuggesztív tanároknak tulajdonított eszközöket és tulajdonságokat. Jámbori Szilvia (2003) az iskolai környezet, a tanár-diák kapcsolat, az osztálylégkör szerepét tanulmányozta a serdülők jövő-orientációjának alakulásában. A tanár-diák kapcsolat korai időszakban betöltött szerepét emeli ki, amikor a tanári viselkedés referenciakeretként müködik a gyermek számára, a kialakuló melegség és bizalom pedig irányadó lehet a további szociális kapcsolatok építésében, emellett elősegítheti a tanulási koncentrációt, motivációt és elköteleződést. Kutatásában feltételezte a támogató tanár-diák kapcsolat és az igazságos bánásmód pozitív hatását a jövő-orientációban. Kovács Zsuzsa (2009) az önszabályozó tanulás egyik legfontosabb ösztönző környezeti elemének a szocio-emocionális hátteret tartja, a biztonságérzet, a bizalmon alapuló tanár-diák kapcsolat szerinte a tanulás fölötti kontrollérzet megjelenésének alapja, a tanárok ennek megteremtésére vonatkozó módszereit kutatásában vizsgálta.

Füzi Beatrix (2012) szerint a kapcsolat érzelmi töltést feltételező kétoldalú viszony. A tanár-diák kapcsolat alapvetően aszimmetrikus természetü, jó esetben kölcsönös tiszteleten alapul. A sikeresség külső megnyilvánulása a pozitív tanár-diák kapcsolat, belső jele a tanár jó közérzete. A tanulók körében sikeres tanárok nem csak a tananyag átadására, hanem emberi értékek közvetítésére is törekszenek. A tanár és diák közötti jó kapcsolat a szükséges érzelmi energiát biztosítja és mozgósítja a motivációt. Suplicz (2012) élettani bizonyítékokkal is alátámasztja az érzelmek emlékezetre, figyelemre, harmonizált és szinkronizált agyi folyamatokra, információk beépülésére tett hatását. A hatékonyságot fokozó érzelmek Füzi (2012) szerint a kapcsolatok személyessége révén mozgósíthatóak. Ennek hiányában a nevelés erejét veszítheti. A kapcsolatot a tanár kezdeményezi, de nem kényszerből, hanem munkája természetes részeként.

Suplicz Sándor (2012) kutatásában többek között a tanár érzelmi szociális jellemzőinek kapcsolatát vizsgálja a tanulói megítéléssel. Szerinte a jó tanár-diák kapcsolat alapja a hatékony munkának, tartalma, minősége, stílusa meghatározza az 
eredményességet. A tanulók érzelmeiket elsősorban a metakommunikáción keresztül juttatják kifejezésre, melynek értelmezése nélkülözhetetlen a jó tanár-diák kapcsolathoz. Fontos, hogy a tanár a diákok jelzéseit reálisan értelmezze, a visszacsatolás pedig őszinte, gyors és reális legyen. Füzi (2012) szerint a tanár érzelmei függnek a személy által generált gondolatoktól is, amelyek révén egyéni értelmezést nyernek. Az érzelmeket és a gondolkodást is befolyásoló tényezőnek tartja a reflexiót, amely a folyamatba való beavatkozás fókuszpontja lehet. A siker vagy sikertelenség mindenképpen hat a tanárra az érzelmein keresztül, befolyással bír hangulatára, viselkedésére, a helyzetek kezelésének módjára, még akkor is, ha a pedagógus nem értelmezi vagy elhárítja a visszajelzéseket. A tanórákon megélt flow-élmények, a tevékenységből nyert önjutalmazás viszont hosszú távon fenntarthatja a motivációt és lelkesedést.

Falus Iván (2001) szerint a megfelelö légkört elfogadás, empátia, pozitív visszajelzések küldése és kongruencia jellemzi. Suplicz (2012) hasonlóan vélekedik, de kiemeli a szeretet és a humor jelentőségét is. Füzi (2012) szerint a tanár által megteremthető pozitív érzelmi minőségre a párbeszéd, a melegség, a támogatás és a lelkesedés jellemző. Az áramlatélmény tanár és diák közös teljesítménye, mely a szellemi összhang megteremtésén és a felek közötti elfogadáson alapul. Kiemeli, hogy az órán alkalmazott módszerek és technikáknál nagyobb jelentősége van annak, hogy a tanár milyen nézetek mentén választja az adott cselekvést. Meglátása szerint azok a módszerek vezetnek legjobb eredményre, melyek az érzelmeket és az érdeklődést is megragadják. Kutatása szerint a sikeres pedagógusok a tanórai terv készítése során érzelmileg is ráhangolódnak a konkrét tanulókra (Füzi, 2007).

Néhány olyan kutatásra is érdemes felhívni a figyelmet, ami a tanár-diák kapcsolat problémáira utal. Paksi és Schmidt (2006) megállapítják, hogy a magyar intézményekben a tanulók részéről kevés bizalom mutatkozik az iskolai szereplők felé, és sejthető az iskola, mint értékközvetítő közeg alacsony hatékonysága. A pedagógusi szerepvesztés okait elsősorban a mentális egészséggel kapcsolatos problémákban látják és ezeket vizsgálták. Az érzelemkifejezés legfontosabb csatornáját képező metakommunikáció pedagógusokra jellemző sajátosságaival Baracsi (2010) foglalkozott. A korábbi kompetenciakutatások eredményeit összegezve felhívja a figyelmet arra, hogy a pedagógusok saját alkalmasságukat vagy nem tudják differenciáltan jellemezni, vagy az tényleg differenciálatlan, és feltünő a tanulók kompetenciájában való bizonytalanságuk is.

\section{Összefoglalás}

Vizsgálatunk alapján elmondható, hogy igen kevés hazai kutatás irányul valamilyen érzelmi tényezőre közvetlenül. A tanári professzió és az osztálytermi folyamatok felé kiterjesztett kutatás során azonban számos olyan adatra és összefüggésre bukkantunk, ami szilárd alapot nyújthat a tanári érzelmek további hazai vizsgálatához. A tanárok érzelmi intelligenciájára vonatkozó kutatások élénkülése 
felhívja a figyelmet a terület súlyához képest elhanyagolt voltára. Az érzelmi kompetenciakutatások hazai megalapozottsága és feltártsága olyan terepet kínál, ahol a tanárok vizsgálata időszerünek mutatkozik. A nézetkutatások elméleti megalapozottságának foka és elterjedtsége is indokolttá teszi a kutatások látószögének bővítését az érzelmekröl alkotott nézetek, az identitás és érzelmek kapcsolatának, valamint az affektív jelenségek és nézetek viszonyának tisztázása irányában.

A kutatásokból kibontakozó kép alapján a tanár elégedettsége inkább belső elemektől függ: meghatározó, hogy a tanulókkal való munkában sikerélményt, képességei kibontakozását élje meg, jó legyen a kapcsolata a diákokkal, szeresse hivatását, legyen pozitív jövőképe, meg tudjon felelni saját ideáljának, érezze szakmai önállóságát, döntésfolyamatokban való részvételét. Pozitív érzelmi állapota többek között ezek érzékeny egyensúlyától függ, melyet a külső tényezők: anyagi és társadalmi megbecsültsége, tárgyi feltételek fokozhatnak vagy felboríthatnak.

A társadalmi, történelmi, kulturális átalakulás többszörös szerepváltást generált a pedagógusok körében. Az ebből fakadó külső-belső konfliktusok, a különböző szereplők elvárásaiból adódó terhek, a kapcsolati szerep előtérbe kerülése, a pálya elnőiesedése, a minőségbiztosítási kényszer összességében olyan képet vázolnak fel, amely a tanárok veszélyeztetett állapotát sejteti, és messzemenően indokolttá teszi az érzelmeikre vonatkozó vizsgálatokat. A folyamatosan változó oktatási környezet érzékenyen hat az egyensúlyi állapotra, kijelölik a tanár mozgásterét, fokozzák vagy csökkentik a rá nehezedő terhek mennyiségét. Az adatok a biztonság iránti igényről, sérülékenységről árulkodnak. Úgy tünik, a döntéshozók még kevéssé számolnak az érzelmek e bonyolult hatásrendszerével, holott az implementáció során ez alapvetően fontos lenne.

A pozitív pszichológia felől számos impulzus érkezik a pedagógia világába, de kérdés, hogy a pedagógusoknak milyen célzott segítségre lenne szükségük. Aggasztó a stresszre és kiégésre vonatkozó kutatások alacsony száma, mely a megalapozott beavatkozások lehetőségét teremthetné meg.

A tanárok elégedettségére és jóllétére, érzelmi intelligenciájára vonatkozó kutatások feltételezik a kapcsolatot pedagógusok és tanulók pozitív állapota között, de feltünő az erre vonatkozó kutatások hiánya és a nemzetközi szakirodalomra történő kis számú hivatkozás, ezért nagy szükség mutatkozik a megfelelő vizsgálatok adaptálására. Az önszabályozó motivációban a tanár érzelmeinek segítő szerepe, a támogató érzelmi légkör kialakítása, a tanár-diák kapcsolat ápolása, a módszertani sikeresség emocionális hátterének további vizsgálata, elmélyítése szintén fontos feladat. Az iskola értékközvetítő szerepének megerősítése, az iskolai élet szereplöi és a tanulók közötti bizalom helyreállítása lelkesedni képes, hiteles, érzelmeikkel bánni tudó, kapcsolatépítésben, konfliktuskezelésben jártas, mentálisan egészséges tanárokkal képzelhető el. 


\section{Irodalom}

Antalka Ágota (2015): A tanári kiégés feltérképezése Kovászna megye középiskolás tanárainak körében. PhD disszertáció. ELTE PPK Neveléstudományi Doktori Iskola.

Bakos Kinga (2015): A pedagógusi szerep dilemmái és összefüggései az életminőséggel. Metszetek, 1. sz. 3-14.

Baracsi Ágnes (2010): Pedagógusok interperszonális kommunikációja. Pedagógusképzés, 23. sz. 21-39.

Baracsi Ágnes (2013): Pedagógusok érzelmi intelligenciája. In: Karlovitz János Tibor és Torgyik Judit (szerk.): Vzdelávanie, Výskum. A Metodológia. International Research Institute s.r.o., Komarno. 480-488.

Bányai Éva és Varga Katalin (2014): Affektív pszichológia. Medicina Könyvkiadó, Budapest.

Bredács Alice (2009): Az érzelmi intelligencia és fejlesztése az iskolában - különös tekintettel a tehetséggondozásra. Iskolakultúra, 5-6. sz. 55-72.

Bullough, R. V. Jr. (2009): Seeking Eudaimonia: The Emotions in Learning to Teach and to Mentor. In: Schutz, P. A. - Zembylas, M. (eds.): Advences in Teacher Emotion Research. The Impact on Teachers'Lives. Springer, New York. 33-55.

Czövek Andrea (2011): Megváltozott tanárszerep és tudásanyag az iskolai gyermekvédelemben. PhD disszertáció. ELTE PPK Neveléstudományi Doktori Iskola.

Day, C. - Quing, G. (2009): Teacher Emotions: Well Being and Effectiveness. In: Schutz, P. A. - Zembylas, M (eds.): Advences in Teacher Emotion Research. The Impact on Teachers' Lives. Springer, New York. 15-33.

Dudás Margit (2006): Pedagógusjelöltek belépő nézeteinek feltárása. PTE BTK Neveléstudományi Intézet, Pécs.

Falus Iván (2001): A gyakorlat pedagógiája. In: Golnhofer Erzsébet - Nahalka István (szerk.): Pedagógusok pedagógiája. Nemzeti Tankönyvkiadó, Budapest. 15-27.

Falus Iván (2004): Bevezetés a pedagógiai kutatás módszereibe. Müszaki Könyvkiadó, Budapest.

Falus Iván (2006): A tanári tevékenység és a pedagógusképzés új útjai. Gondolat Kiadó, Budapest.

Frenzel, A. (2014): Teacher Emotions. In: Pekrun R. - Linnenbrink-Garcia, E. A. (eds.): International Handbook of Emotions in Education. Routledge, New York. 494-519.

Fried, L. - Mansfield, C. - Dobozy, E. (2015): Teacher emotion research: Introducing a conceptual model of guide future research. Issues in Educational Research, Nr. 4. 415-441.

Füzi Beatrix (2007): A sikeres pedagógiai munka néhány összetevője egy vizsgálat tükrében. Pedagógusképzés, 3. sz. 9-30.

Fűzi Beatrix (2012): A tanári munka sikeressége a pedagógiai attitüdök, a tanár-diák viszony és az iskolai élmények összefüggésrendszerében. PhD disszertáció. ELTE PPK Neveléstudományi Doktori Iskola.

Gáspár Mihály - Holecz Anita (2005): Pályaszocializáció és személyiségvonások a pedagóguspálya szempontjából. Pedagógusképzés, 2. sz. 23-40.

Golnhofer Erzsébet - Nahalka István (2001. szerk.): A pedagógusok pedagógiája. Nemzeti Tankönyvkiadó, Budapest.

Gombos Katalin - Bányai Éva - Varga Katalin (2009): A tanulás affektív pszichológiai 
nézőpontból. Pedagógusképzés, 2-3. sz. 103-127.

Halász Gábor (2015): Pedagógusszakma, pedagógusmunka és személyes adottságok. A pedagógusok pályamotivációit vizsgáló kutatás eredményeinek hasznositása. Oktatási Hivatal, Budapest.

Hamvai Csaba - Pikó Bettina (2008): Pozitív pszichológiai szempontok az iskola világában: a pozitív pedagógia kihívásai. Magyar Pedagógia, 1. sz. 71-92.

Harangi Lőrinc (2003): A tanári elégedettség két hatásáról: avagy mi állhat a késés, ill. a pályaelhagyás hátterében? Educatio, 2. sz. 305-308.

Harangi Lörinc (2004): A tanári elégedettségröl. Egy 2003. márciusi vizsgálat eredményei. Iskolakultúra, 1. sz. 14-23.

Hargreaves, A.(1998): The Emotional Practise of Teaching. Teaching and Teacher Education, Nr. 8. 835-854.

Hargreaves, A. (2001): Emotional Geographies of Teaching. Teachers College Record, Nr. 6. 1056-1080.

Hargreaves, A. (2008): The Emotional Geographies of Educational Leadership. In: Davies, B. - Brighouse, T. (eds.): Passionate Leadership in Education. Sage Publications, London. 129-150.

Hegyiné Ferch Gabriella (2001): Az érzelmi intelligencia szerepe a nevelői munkában. Új Pedagógiai Szemle, 7-8. sz. 8-19.

Hercz Mária (2005): Pedagógusok szakember- és gyermekképe (gondolatok a kognitív fejlődésről vallott nézetek megismerésének tükrében). Magyar Pedagógia, 2. sz. 153184.

Hercz Mária (2007): A pedagógusok gondolkodása a gyermekek kognitív fejlődéséről és fejlesztéséről. PhD értekezés. Szegedi Tudományegyetem Neveléstudományi Doktori Iskola.

Holecz Anita (2015): A pedagógusok pszichés fejlödését segitő képzési feladatok és lehetöségek a tanárképzés és továbbképzés rendszerében. In: Kispálné Horváth Mária (szerk.): Tanulmányok a pedagógusképzés 21. századi fejlesztéséhez. Nyugatmagyarországi Egyetem Regionális Pedagógiai Szolgáltató és Kutató Központ, Szombathely. 145-164.

Holecz Anita - Molnár Szandra (2014): Pedagógusok pozitív pszichológiai tükörben: a jóllétet erősítő tényezők jellemzői a pályán. Iskolakultúra, 10. sz. 3-15.

Hunyady György (2015): Tanárgenerációk nézetei: értékek, attitüdök, megítélések. In: Felvinczi Katalin (szerk.): Problémafókuszú pedagógusképzés. ELTE Eötvös Kiadó, Budapest. 89-154.

Jámbori Szilvia (2003): Az iskolai környezet szerepe a serdülők jövő-orientációjának alakulásában. Magyar Pedagógia, 4. sz. 481-497.

Józsa Krisztián - Fejes József Balázs (2012): A tanulás affektív tényezői. In: Csapó Benő (szerk.): Mérlegen a magyar iskola. Nemzeti Tankönyvkiadó, Budapest. 367-406.

Kasik László (2015): Személyközi problémák és megoldásuk. Gondolat Kiadó, Budapest.

Katona Nóra (2009): Motiváció és önszabályozó tanulás. Pedagógusképzés, 2-3. sz. 129159.

Kazal Kolos (2009): „Pedagógusként sokáig nem tudtam mit kezdeni ezzel a problémával, de ma már félelem nélkül megyek be az óráimra...”: Privát levél egy pedagógustól. Tanitó, 10. sz. 7.

Kálmán Orsolya (2009): A hallgatók tanulási szokásai és ezek változása. $\mathrm{PhD}$ disszertáció. 
ELTE PPK Neveléstudományi Doktori Iskola.

Kálmán Orsolya (2013): A pedagógusjelöltek és pedagógusok nézetei - hazai kutatások nemzetközi kontextusban. In: Kotschy Beáta (szerk.): Új utak a pedagóguskutatásban. Tanulmánykötet Falus Iván tiszteletére. Líceum Kiadó, Eger. 81-104.

Kissné Gombos Katalin (2009): Az oktatás, nevelés érzelmi háttere affektív pszichológiai szempontból. Sárospataki Pedagógiai Füzetek, 26. sz. 43-50.

Kovács Edina (2011): A tanári identitás alakulása a társadalmi nemi szerepek tükrében. In: Kéri Katalin (szerk.): Társadalmi nem és oktatás. URL: http://mek.oszk.hu/ Utolsó letöltés ideje: 2016.09.18.

Kovács Zsuzsa (2009): Az önszabályozó tanulást támogató osztálytermi környezet sajátosságai. PhD disszertáció. ELTE PPK Neveléstudományi Doktori Iskola.

Mesterházy Mária - Vámos Ágnes (2016): Pedagógusok nézetei az érzelmi kompetenciáról. Iskolakultúra, 11. sz. 16-34.

Oláh Attila (2005): Érzelmek, megküzdés és optimális élmény. Trefort Kiadó, Budapest.

Oplatka, I. (2009): Emotion Management and Display in Teaching: Some Ethical and Moral Considerations in the Era of Marketization and Commercialisation. In: Schutz, P. A. - Zembylas, Z. (eds.): Advences in Teacher Emotion Research. The Impact on Teachers' Lives. Springer, New York. 55-73.

Paksi Borbála - Schmidt Andrea (2006): Pedagógusok mentálhigiénés állapota. Új Pedagógiai Szemle, 6. sz. 48-64.

Pauwlik Zsuzsa - Margitics Ferenc (2008): Pedagógusjelöltek érzelmi intelligenciája. Új Pedagógia Szemle, 6-7. sz. 37-46.

Pekrun, R. - Schutz, P. A. (2007): Where do we go from here? Implications and future directions for inquiry on emotions in education. In: Schutz, P. A. - Pekrun, R. (eds.): Emotion in Education. Elsevier, Burlington, MA. 313-331.

Pekrun, R. - Linnenbrink-Garcia, E. (2014): Introduction to Emotions in Education. In: Pekrun, R. - Linnenbrink-Garcia, E. (eds.): International Handbook of Emotions in Education. Routledge, New York. 1-10.

Petticrew, M. - Roberts, H. (2006): Systematic Reviews in the Social Sciences. A practical guide. Brackwell, Malden, MA.

Pléh Csaba (2014): Az érzelem- és mozgatóerő-kutatás múltja. In: Bányai Éva - Varga Katalin (szerk.): Affektív pszichológia. Medicina Könyvkiadó, Budapest. 71-83.

Rapos Nóra (2003): Az iskolai félelmek világa. Iskolakultúra, 13. sz. 107-112

Reinhardt Melinda (2009): Miért hasznosak a pozitív érzelmek iskolai környezetben? Iskolakultúra, 9. sz. 24-45.

Réthy Endréné (2015): Elégedettség, boldogság, jóllét tanuló tanárok körében. Palatia Kiadó, Győr.

Rosiek, J. - Baghetto, R. O. (2009): Emotional Scaffolding: The Emotional and Imaginative Dimensions of Teaching and Learning. In: Schutz, P. A. - Zembylas, Z. (eds.): Advences in Teacher Emotion Research. The Impact on Teachers' Lives. Springer, New York. 175-195.

Salavecz Gyöngyvér - Neculai Krisztina (2006): Pedagógusok mentális egészsége a munkahelyi stressz és a megküzdés szempontjából. Pedagógusképzés, 1-2. sz. 17-30.

Saric, M. (2015): Teachers' emotions: a research review from a psychological perspective. Journal of Contemporary Educational Studies, Nr. 4. 10-26. 
Schutz, P. A. (2014): Inquiry on Teachers' Emotion. Educational Psychologist, Nr. 1. 1-12.

Schutz, P. A. - Cross, D. I. - Hong, J. Y. - Osbon, J. N. (2007): Teacher Identities, Beliefs and Goals Related to Emotions in the Classroom. In: Schutz, P. A. - Pekrun, R. (eds.): Emotion in Education. Elsevier, Burlington MA. 223-241.

Séllei Beatrix (2016): A pedagógustársadalom érzelmi térképe. Neveléstudomány, 4. sz. 6577.

Suplicz Sándor (2012): Tanárok pszichológiai jellemzői diákszemmel. PhD disszertáció. Debreceni Egyetem Humán Tudományok doktori iskolája.

Sutton, R. E. - Wheatley, K. F. (2003): Teachers' Emotions and Teaching: A Review of the Literature and Directions for Future Research. Educational Psychology Review, Nr. 4. 327-358.

Szabadi Magdolna (2016a): Az affektív-szociális kompetencia kérdőív: a fejlesztés folyamata és az értékelők müködésének feltárása. Magyar Pedagógia, 4. sz. 383-402.

Szabadi Magdolna (2016b): A szociális kompetencia érzelmi elemeinek fejlesztése zeneterápiás eszközökkel tanár szakos hallgatók körében. Iskolakultúra, 6. sz. 14-29.

Szebeni Rita (2010): A kompetencia alapú oktatás pedagógus személyiség háttere. PhD disszertáció. Debreceni Egyetem Humán Tudományok doktori iskolája.

Szelezsánné Egyed Dóra (2016): A pedagógusok körében megjelenő stressz, pszichoterror és kiégés jelensége; prevenciós és kezelési lehetőségek a köznevelési intézményekben. Opus et Educatio, 5. sz. 590-603.

Tóth Edit (2011): Pedagógusok nézetei a tanulóiteljesítmény-mérésekről. Magyar Pedagógia, 3. sz. 225-249.

Tóth Edit (2015): Az országos kompetenciamérés hatása. Magyar Pedagógia, 2. sz. 115-138.

Tóth Edit - Kasik László (2010): A szociális kompetencia főbb fejlesztési koncepciói és a pedagógusok szerepe a fejlesztésben. In: Zsolnai Anikó - Kasik László (szerk.): A szociális kompetencia fejlesztésének elméleti és gyakorlati alapjai: tanulmánygyüjtemény. Tankönyvkiadó, Budapest. 163-182.

Tóth Edit - Sipos Judit (2014): A rendszerszintü mérések hatása a pedagógusok tanítási gyakorlatára: egy tanári kérdőíves vizsgálat tanulságai. Iskolakultúra, 10. sz. 38-52.

Thun Éva (2012): A pedagógusnők identitástudata. PhD disszertáció. ELTE PPK Neveléstudományi Doktori Iskola.

Van Veen, K. - Sleegers, P. (2006): How does it feel? Teachers' emotions in a context of change. Journal of Curriculum Studies, Nr. 1. 85-111.

Yassur, E. (2001): A szervezeti légkör és az iskola vezetési stílusának összefüggései. Magyar Pedagógia, 2. sz. 171-190.

Zembylas, M. (2010): Emotions and Teacher Identiy: A poststructural perspective. Teachers and Teaching theory and practice. Nr. 3. 213-238.

Zsolnai Anikó (2004): A tanári munkához szükséges szociális készségek. In: Dombi Alice Oláh János - Varga István (szerk.): A neveléselmélet alapkérdései. Tanulmányok. APC-Stúdió, Gyula. 323-333.

Zsolnai Anikó (2015): Social and emotional competence. Hungarian Educational Research Journal, 1. sz. 1-10.

Zsolnai Anikó - Kasik László (2007): Az érzelmek szerepe a szociális kompetencia müködésében. Új Pedagógiai Szemle, 7-8. sz. 3-15.

Zsolnai Anikó - Rácz Anna - Rácz Kata (2008): Szociális és érzelmi tanulás az iskolában. Iskolakultúra, 10. sz. 59-68. 